\title{
Simplifying a deltaic labyrinth: anthropogenic imprint on river deltas
}

\author{
Ștefan CONSTANTINESCU ${ }^{1^{*}}$, Mihnea TĂNĂSESCU \\ ${ }^{1}$ Faculty of Geography, University of Bucharest, Bucharest, Romania \\ ${ }^{2}$ Research Foundation Flanders (FWO), Vrije Universiteit Brussel (VUB), Brussels, Belgium \\ Received 30 May 2018; Revised 15 September; Accepted 25 September \\ *Correspondence to: Ștefan CONSTANTINESCU, e-mail: stefan.t.constantinescu@gmail.com
}

\begin{abstract}
The information contained by historical maps provides a good source of understanding the complex transformation of a deltaic environment by human activity. Using the Danube delta as an example, here we show that a cartographic diagnosis for river deltas is based on four main steps that outline the learning stages for every similar area: 1) exploring coasts (for the early stages of the portolan and Ptolemaic maps); 2) exploring depths (for the succeeding imperial and military maps which focused on the access along the deltaic distributaries); 3) exploring deltaic networks (when economic and ecological reasons led to detailed topographic maps based on field measurements and aerial photos); 4) ecological protectionism (when ecological reasons dictate land use patterns and determine land use change). This synopsis is applicable to other river deltas with some adaptations imposed by the local context. We interpret the four stages in the description of the Delta as resting on and further reinforcing the power of the centre to dictate the uses of the periphery. We further argue that the way the territory is lived by local inhabitants is continuously marginalized and effaced. This stands in the way of future adaptive strategies.
\end{abstract}

KEYWORDS

Danube delta; anthropogenic imprint; Black Sea; river deltas; human ecology; Anthropocene

\section{Introduction}

Sedimentary, paleoenvironmental and paleogenetic evidence shows us that land use occurred in both the Danube Delta and the Black Sea basin well before the Industrial Revolution started (Giosan et al., 2012). The information about the anthropogenic footprint contained by maps can play a considerable role in understanding the alteration of the environment, highlighting the changes produced in the last centuries. The human impact on the environment is also reflected by the relationship between mapping and governance which is both pervasive and power- 
ful (Akerman, 2009). Maps always served as a primary technology of administration that governments used to extend their authority and control new territories or grab land (Edney, 2009). They can also be interpreted as fundamental justifications for later activities in the charted territories, means by which power extends outwards from the centre to the periphery. As we will see, mapping the Delta has gone hand in hand with transforming it to better fit a flat and rational approach to the territory.

The map in this view is not a benign representation of the territory, but rather one crucial aspect of the wielding of power (Elden, 2013; Steinberg, 2009). Therefore, the changes we trace in cartographical production reflect both changes to the territory and to the wielding of power in that territory. Studying the progressive changes in maps together with the progressive transformation of the Delta and its uses shows different stages of knowledge corresponding to different stages of use and control (see Figure 2). This is so in two senses: what the maps do not show becomes part of the justification for later activities in the territory, and changes to the territory are mostly achieved through the dominance of a cartographical mentality. In other words, portraying the Delta as empty (so not showing settlements) allows greater access to it, and remaking the physical Delta into a flatter space starts with the engineering exercise of plotting what one wishes were the case. These two aspects of cartographical knowledge are here shown inseparable.

Population and economic growth had a profound impact on deltas (Vörösmarty et al., 2009; Syvitski et al., 2009). Similarly, human engineering has had a considerable influence on the evolution of many wetlands (Syvitski and Saito, 2007; Giosan et al., 2013). However, wetlands have not traditionally been easy to chart, accessibility having been the main problem for a cartographic approach (the shallow water and marshes act as natural barriers). Furthermore, cartographical approaches have not been particularly well equipped to deal with the dynamism of a deltaic environment: neither fully water nor solid land, a delta is an environment inbetween that constantly changes and frustrates attempts to define and draw it narrowly. It is there- fore best understood as a dynamic volume (also see Steinberg and Peters, 2015).

Consequently, a deltaic space has always been a refuge for political castaways and a protective barrier between empires. The Danube Delta and its floodplain are the best European example of a buffer zone between the Ottoman, Russian or Austro-Hungarian Empires (Fig. 1). This was a space with ethnic and religious diversity, with populations of Romanians, Russians, Turks, Germans, and Bulgarians (Enăchescu, 2013). The frequent changes of borders, following the frequent conflicts between Christendom and the Islamic world, involved an increasing cartographical effort for collecting data. From the $18^{\text {th }}$ and $19^{\text {th }}$ centuries, Austrian or Russian officers undertook new topographical surveys with a stress on accurate mathematical precision. The changes of borders can themselves be interpreted as occasioned by the Delta's fundamental liquidity a space of flows and volumes that has always challenged the cartographical attempt of laying out a flat territory. The new cartographical results became highly important in time of peace, when the economic powers exercised their supremacy and used the Danube River as a principal route for goods transport (Constantinescu et al., 2010).

\subsection{Aims and Scope of the article}

Using a large cartographical database, complemented with interdisciplinary methods (see below), we develop a four-stage evolution in the knowledge of the Danube delta, applicable to other deltas as well. Through the four stages, we show the anthropogenic imprint on river deltas advancing together with changing uses of the territory and changing conceptualizations of it from the point of view of the centre of power. In other words, we will show that the Danube Delta has gone through four different phases of cartographic knowledge, each interpreted as both occasioning and being occasioned by the changing uses of the territory. The transportation of goods was aided by the charting of the main branches, but also led to their eventual shortening and the maintenance of artificial depths. This increasing access to the interior of the Delta eventually led to the cartographic exploration of the network of channels and lakes at the heart of the 
territory, which allowed greater exploitation of fish and reed resources. In turn, these activities fed a transformation of the deltaic labyrinth into a navigable, accessible, eminently mappable space. The stages we propose arrive to today's ecological protectionism, which we will show to be inscribed in the same logic of cartographical knowledge understood as wielding power and 'taming' previously unknown lands.

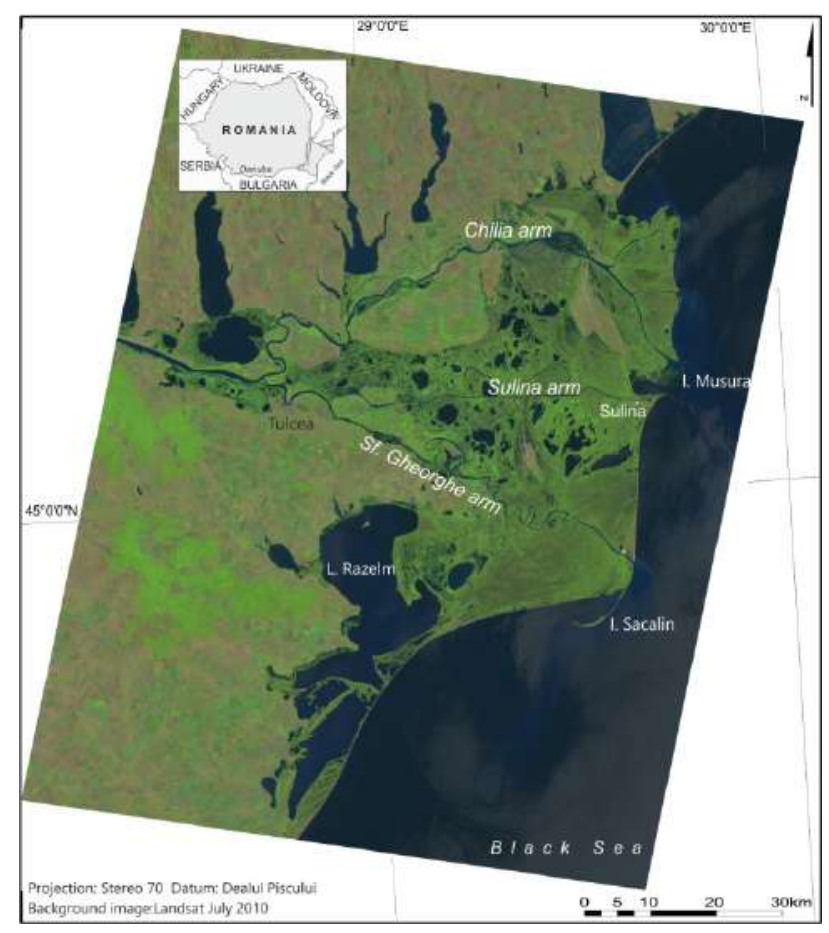

Figure 1 Danube delta

\section{Study area}

Crossing ten countries and collecting its water from 19 others, the Danube is the most international river on Earth, flowing over 2,870 km from the Black Forest Mountains (Germany) to the Black Sea (Romania). The average water discharge is $6,470 \mathrm{~m}^{3} / \mathrm{s}$ and the sediment discharge is $1,555 \mathrm{~kg} / \mathrm{s}$ with a catchment area covering $817,000 \mathrm{~km}^{2}$ (McCarney-Castle et al., 2012).

The extent of anthropic impact in the Danube Delta was largely decided at the beginning of the $20^{\text {th }}$ century, when two different models were envisioned for the Danube floodplain: an engineering model proposed to drain the floodplain for agriculture (Ionescu-Sisești, 1933), and a natural solution suggested the development of fish farms and ani- mal husbandry while preserving the system of lakes and marshes (Antipa, 1914). Though Antipa's model managed to initially stave off massive engineering interventions in the Delta, the first model was implemented on a large scale after 1950, including now 56 embanked enclosures (Constantinescu et al., 2015). The effect on the water regime was significant: the artificial levees produced a narrowing of the stream bed with an increase in flood events, lateral or incision erosion.

The anthropogenic intervention in the Danube basin is significant, with 56 reservoirs along the river and more than 300 in the catchment area after 1945, of which 50\% exist in Romania (Stanciu et al., 2008). Although the energy production is considered significant, the overlooked effect of these dams is the $60 \%$ decrease of the sediment supply transported by the river (McCarney-Castle et al., 2012). In Romania, the length of the Danube course is 993.5 $\mathrm{km}$ and the floodplain covers 573,000 ha, of which $75 \%$ is embanked (Constantinescu et al., 2015). The river also provides over $60 \%$ of the entire runoff reaching the Black Sea generating a strong coupling between fluvial fluxes and the marine biogeochemistry and ecology (Kideys, 2002; Syvitski, 2005; Giosan et al., 2012).

\section{Data and Methods}

Although a large number of materials were produced before the $19^{\text {th }}$ century, they were made without a cartographic projection and coordinates. Those maps reflect just a general aspect of the Delta, focusing only on the main navigable arms. Accurate documents were published from the $19^{\text {th }}$ century onward, with precise measurements, after the Crimean War: Russian maps (1830, 1854, 1856), Manganari (1841), Spratt (1856), E.C.D. (1867, 1874, 1887, 1902), the General Staff of the Army (1884), Vidrașcu (1911). After the Second World War, during the Communist regime, major topographical surveys were conducted (1960, 1980) using a particular projection used in the Soviet states, Gauss-Kruger.

In on our previous papers (Constantinescu et al., 2010; Constantinescu, 2014) we investigated cartographical products regarding the Danube Delta, indexing maps and analysing the topographical techniques involved. For the present study, we 
chose only maps that constituted original contributions, created from topographical field surveys, in order to be integrated into a GIS database:

- Maps belonging to the European Commission of the Danube $(1856,1886,1926)$;

- General Staff of the Army (Harta Marelui Stat Major: 1880-1884) and derived maps like Planurile Directoare de Tragere (1920s-1930s);

- Vidrașcu map from 1909-1911;

- Danube navigational charts (1934-1935);

- Topographic maps of Danube Delta $(1960,1980)$;

- Soviet topographic maps (1980).

Georeferencing was made in the native cartographic projection (Mercator, Lambert-Cholesky, Gauss-Kruger, and UTM) with the transformation of the national grid, currently called Stereo-70. All the maps were digitised in QGIS 2.18 extracting arms and lakes, natural and artificial channels, levees, permanent and temporary settlements. Starting with Landsat missions, the maps' production took a different approach, with two images per month showing the Delta at an unprecedented temporal resolution. Later the Romanian authorities (ANCPI) created a national aerial mosaic at a spatial resolution of 0.5 $\mathrm{m}$ (2005-2012). The last product was used to extract the same layers, to create a present-day image of the entire delta, a century after the Vidrașcu map. Finally, the results were integrated into a PostGIS database and compared in order to understand the anthropogenic imprint on this territory. Derived products which we called mirror maps were created later, like those in Figure 4.

This map archive was complemented by interviews with locals of Sfântu Gheorghe village and participant observation spanning three years, from 2014 until 2017. Historical sources detailing the uses of the deltaic space in different time periods were also consulted (Dorondel, 2005; Van Assche et al., 2009; Van Assche et al., 2011a, 2011b; Van Assche et al., 2012; Iordachi and Van Assche, 2015; von Hardenberg, 2017; Gătejel 2016, 2017; Tănăsescu, 2017). Lastly, the current legal framework applicable to the Danube Delta was studied in order to accurately define the current period of ecological protectionism (also see Dorondel and Mitroi, 2017; Prelz Oltramonti and Tănăsescu, 2018). This legal study was complemented by the qualitative data mentioned above.

Starting from the information contained in old maps (former lakes or natural channels) a new topographical map of the delta was created (see supplementary material). This new cartographical product can offer an image of the deltaic space that includes human-induced environments but does not exclude the original natural landscape. Some toponyms have survived in local communities reminding us that a former lake, forest or creek existed in that space and our map brings them back into the present. Another electronic version was created and published using Mapbox and TileMill, available at http://tinyurl.com/zrkhcno. This map visualizes the cumulative dynamism of the Delta, showing both historical baselines and current use. The juxtaposition of natural state and anthropic impact can start giving an idea of the extent of change that we conceptualize and explain throughout this paper.

\section{Results and discussion}

Following the anthropogenic imprint in this inaccessible territory, different stages of knowledge result each corresponding to different modes of wielding power in the mapped space. Based on the cartographical evidence, there are four main phases that define the learning stages which can describe every deltaic area (see Figure 2):

1) Exploring coasts: for the early stages of the portolan charts and Ptolemaic maps.

2) Exploring depths: for the succeeding imperial and military maps which focused on the access along the deltaic distributaries.

3) Exploring deltaic networks: when economic and ecological reasons led to detailed topographic maps based on field measurements and aerial photos.

4) Ecological Protectionism: after the Danube Delta received a Biosphere Reserve status (1991).

From Antiquity to the $18^{\text {th }}$ century, a descriptive and pictorial style persisted in the case of portolan charts. The technological capacity of using the deltaic territory at the time being very limited, it conditioned the ways in which the Delta could be known. It was therefore more inscribed within a symbolic order that nonetheless served the purpose of integrating the relatively unknown territory into the 
known world order. The development of mathematical cartography allowed for the production of new topographic surveys based on military needs. The technological advancements of mathematical cartography worked together with the expansion of naval power to inscribe the territory of the Delta within first a military, and then an economic phase. The most important data in this period is bathymetry, precisely because the exploration of the territory and its use go hand in hand. Finally, the networks in the interior of the Delta are mapped and these serve a deepening of economic exploitation before a protectionist approach settles in. These phases of knowledge, reflected and reflective of uses of the territory and allied technologies, seem very different from each other. However, besides being connected by the enabling role of the map in the exercise of power, they are also connected by the assumption of the deltaic space as fundamentally empty of an important local perspective. The stages of cartographical exploration reproduce a familiar dynamic of a central power exploring peripheral spaces, a process which consolidates the grip of the centre over the marginal (but highly important) land. Importantly, in describing the land as fundamentally empty the terrain is prepared for later interventions aimed at flattening the complex deltaic labyrinth and making its resources more available. In this process the map is the supreme means.

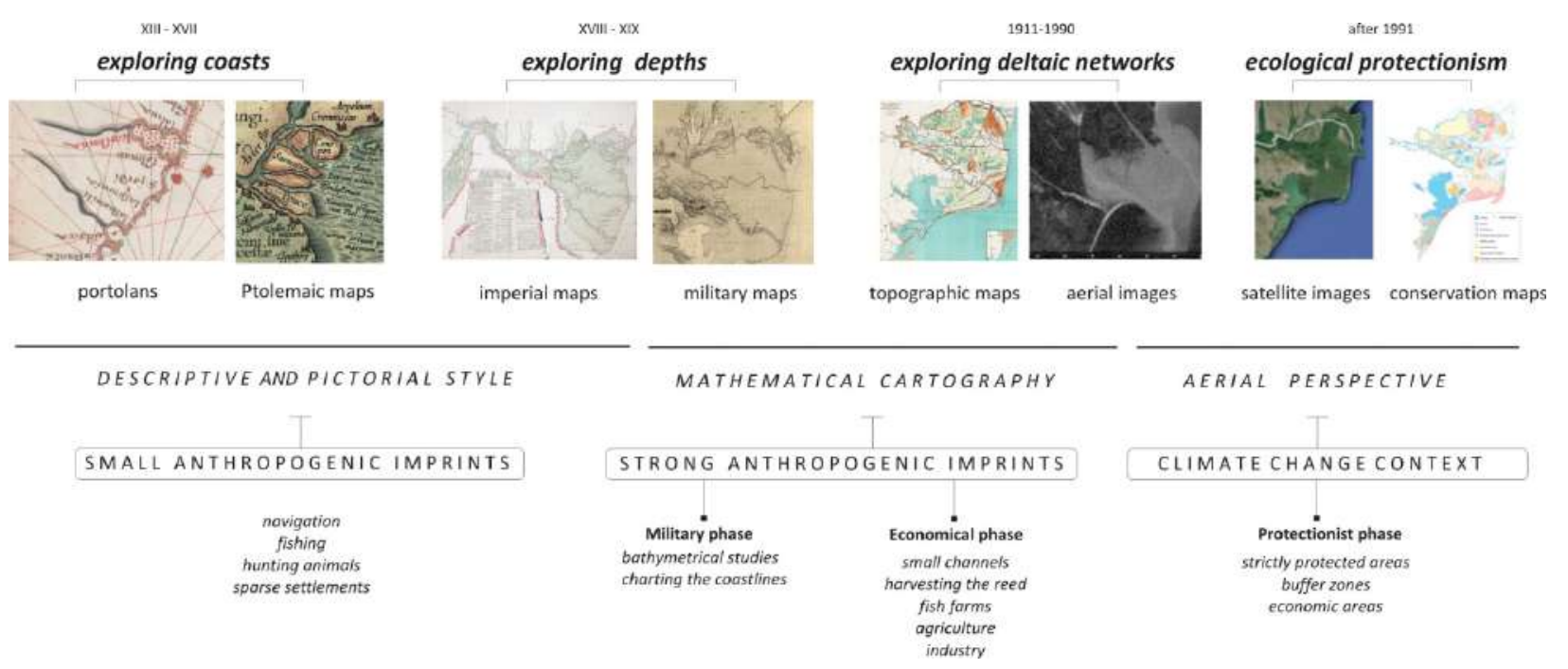

Figure 2 The scenario of cartographical knowledge regarding the Danube Delta

\subsection{The Descriptive and Pictorial Style}

Historical texts can yield enough information about coastline configuration, distances between river mouths or the time required for traveling between two cities. Before the appearance of the portolan charts a symbolic image of the world persisted, characterized by a profound Christian influence. The most prominent were the examples of the mappa mundi or imago mundi. From the $13^{\text {th }}$ century, the new cartographic products (i.e. portolans) created an accurate shorelines' representation across the Mediterranean and the Black Sea basins. The deltaic context is usually reduced to the river mouths and coastline, with a space between the arms. In the $16^{\text {th }}-17^{\text {th }}$ centuries, there was a combination of old information (Greek or Roman sources based on a Ptolemaic representation) with accurate descriptions of travellers or military officers, yet insufficient to create reliable maps. In other words, the space was not rendered economically accessible by this stage of cartographic knowledge. Rather, it was inscribed in an established symbolic order, therefore aiding the continuation of this order. The decorative purpose in this stage is clear, and this resulted in the confusion which persisted in either the positioning of the settlements or the river mouths or islands' names, especially in an exotic part of Mare Maggiore. The presence of the Venetian or the Genovese ships is illustrated on maps with the flags of their cities. Since the most frequent activity was trading 
with cabotage navigation, these vessels primarily undertook the coasts' exploration. However, there is a persistent lack of information about the territory between the Delta's main branches and this makes the landscape mysterious and unfit for detailed exploration.

Nonetheless, several lakes or creeks are specified, meaning that the space between arms was unreachable or did not present military interest. The navigation from the Black Sea to the upstream commercial ports on the Danube was achieved along the main arms, Sulina being the most used, which is why bathymetry was the most sought-after information that a map could provide at this time.

Descriptive boxes complete the graphical support with a focus on navigational issues (depth, dangerous points, and mouth-bar conditions). Huge empty spaces, between the main arms, suggest a no man's land sort of territory. Moreover, the anthropogenic footprints can be distinguished along the river, where the sparse settlements were offering a vague insight into an unknown land, dominated by wilderness. Fishing, reed harvesting and hunting were the only forms of anthropogenic pressure, focused particularly on the main arms, where there were just a few isolated villages and a single town, Sulina. That period could be regarded as one characterized by a type of human activity that did not fundamentally interfere with natural processes. As we know from other areas that were primarily thought of as wilderness (see Ter Steege et al., 2013, Levis et al., 2017), such as the Amazon basin, the habitation of biodiverse and rich ecological spaces likely results in their transformation. The question is whether this transformation was overall benign for ecological health or not. However, in this early period of cartographical exploration human habitation was supposed insignificant, if supposed at all.

\subsection{Mathematical Cartography}

At the crossroad of three empires (the Ottoman, the Russian and the Austro-Hungarian one), the Danube Delta was a marginal territory with frequent changes of borders. However, this political instability presented some cartographical advantages: Austrian and Russian officers created detailed sur- veys, and focused their interest on the Danube's arms, where they took water depth measurements. The most outstanding product is a Russian map from 1771 with a German version (1778) and a French edition at the end of the $18^{\text {th }}$ century. Depth measurements were a crucial precursor to a new kind of exploration of the Delta's interior. The map of the Delta is slowly beginning to aid physical access to the heart of the territory.

The political consequences after the Crimean War led to a new European organisation, responsible for maintaining river navigation: the European Commission of the Danube (ECD). It was a flourishing period of cartography, with new products published in several atlases and many studies, which were later kept in the archives (Constantinescu et al., 2010; Constantinescu, 2014; Budileanu, 2013). A first product, developed by Captain Thomas Abel Spratt in 1856 was based on accurate topographical surveys, without going inland into the marshes, showing the familiar image dominated by three arms and a few secondary courses.

The main anthropogenic pressure in this period was exercised along Sulina channel where a jetty structure was built, first at the river mouth, then followed by the shortening and the dredging of the river upstream (Fig. 3A). This was followed by the dense bathymetrical points measurements a few miles offshore, coastal morphometry having the same importance as the fluvial one. Between 1880 and 1902, the total length of the sectors dredged on Sulina channel was $31.9 \mathrm{~km}$, accumulating a volume of $24 \mathrm{Mm}^{3}$. The entire maritime channel must have a minimum depth of 24 feet $(7.32 \mathrm{~m})$. This first engineering intervention in the Delta marks a change from cartographic knowledge of a fundamentally unknown territory to the active creation of territories that would neatly fit a navigational map. The Sulina arm is shortened and its depth kept a predictable constant, and this is a radical new step in literally making a territory that renders itself accessible to the activities that the powers of the time saw fit (also see Cioc, 2002; Blackbourn, 2011; Pritchard, 2011), in this case mostly trade and navigation. 

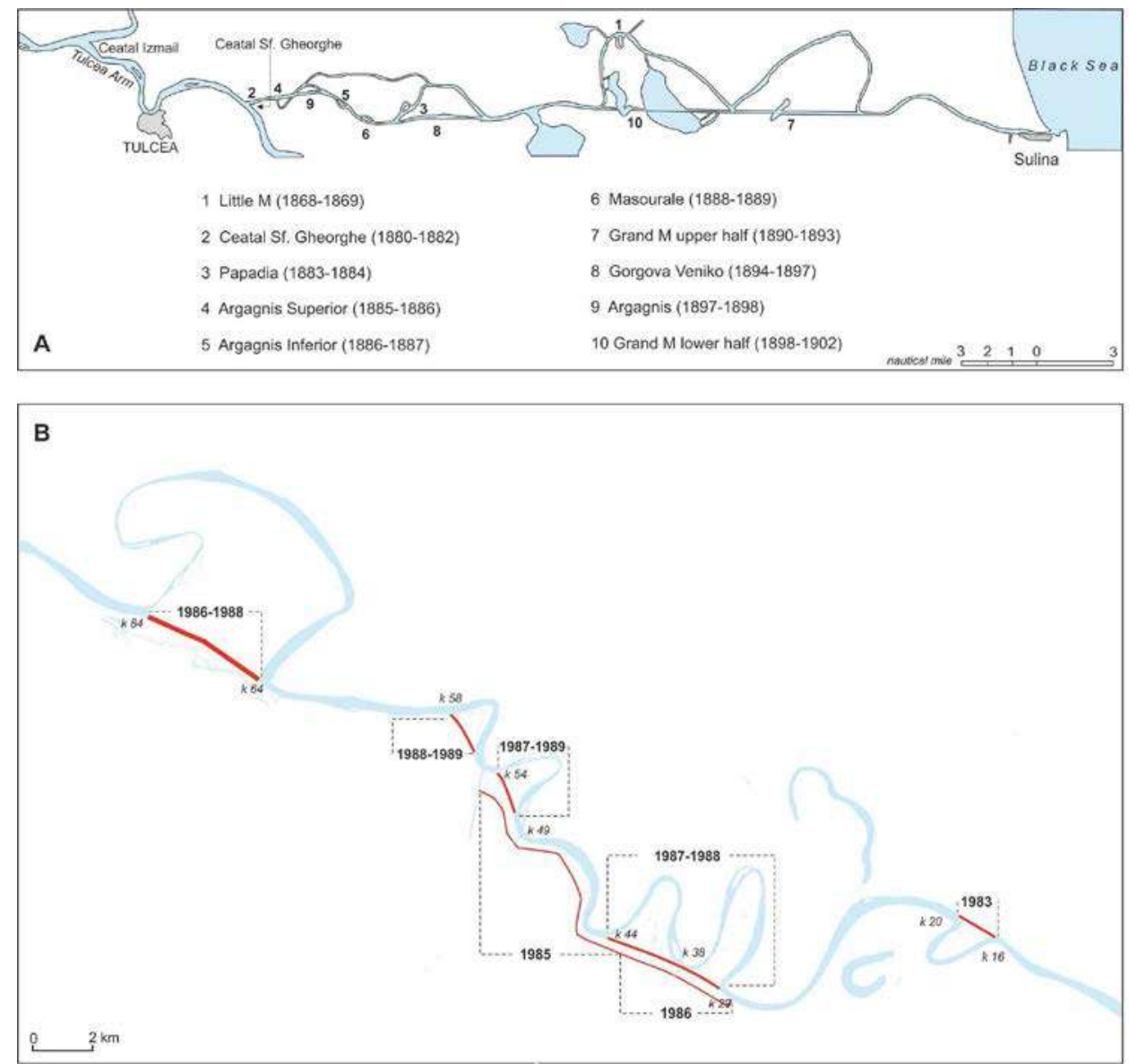

Figure 3 A. Shortening Sulina arm and transforming into a maritime navigational channel (after Rosetti and Rey, 1931); B. New channels cut along Sf. Gheorghe arm based on Landsat images

From the beginning of the $20^{\text {th }}$ century, the focus shifted to fishing activities, as the Romanian authorities sought economic benefits and territorial consolidation. For the Romanian state the new, unknown, territory represented a great possibility for natural resource extraction. Grigore Antipa was tasked in 1893 with devising fisheries in the Danube Delta in order to exploit existing stocks. By 1895, he drafted a study of Romanian fisheries (Antipa, 1895) that set the basis for the 1896 fishing law that institutionalizes Antipa's recommendations for the rational exploitation of fish stocks (Dorondel and $\mathrm{Mi}$ troi, 2017). He sought to increase fish production through paying close attention to local hydrological conditions and modifying the deltaic space to increase beneficial conditions and mitigate problematic ones. Under his leadership, the state sought to reverse the silting of lakes, a natural process that leads to the deterioration of fish stocks, by dredging channels and cutting new ones.
New channels were cut along the natural river course, shortening the distances and increasing the water depth for bigger boats: Dunavăț (1907), Enisala (1913), Dranov (1914), Litcov (1928-1932), Crasnicol (1930-1934). The purpose was to obtain more productive fish stocks exploitation from the lakes situated in the interior of the delta. The width of the channels varies between 9 and $18 \mathrm{~m}$ with a projected depth of 1.60-4.50 m. And the most difficult task was then to maintain a depth greater than $1.6 \mathrm{~m}$ (Rudescu et al., 1965). The natural process of sediment accumulation constantly fought, and still fights, the transformation of the Delta into an easily navigable fishing pond. The 'tapping into' the riches of the Delta relied on the previous definition of the deltaic space as a no man's land or pure wilderness. In other words, there were no other competing claims to the richness of the territory worth taking into account. In this manner, the first phase of exploration and its supposition of empty land make 
possible the next stages, which see it as a matter of course that the Delta is there to be exploited by those that define it (and not, for example, by those that live there). As Gătejel (2018) chronicles, "the engineers and commissioners in the Danube Delta quite often discarded previous local practices of river management as irrelevant for their work, instead relying exclusively on their own methods of observation and calculation". The engineering intervention then further solidifies the claim of the central power to the territory.

After 1878 (the Treaty of Berlin), the national borders underwent some major changes in Eastern Europe and, consequently, the Dobrogea region became part of Romania. Therefore, the new provinces needed to be connected with the older ones from a cartographical point of view, and this was a challenge.

Between 1909 and 1911, Gheorghe Vidrașcu developed a cartographical masterpiece, the most complete map of the Danube Delta at the time. The space between the arms, missing from previous materials, revealed a network of lakes and channels. Many fisheries were depicted in the interior of the Delta with permanent and temporary settlements that evoked a human presence rooted in the natural environment. The main activities were conducted along the Sulina channel, but some land-based routes could be identified along the natural levees. Those roads corresponded to animal farming activities, which increased after 1878. This revelation of the network of channels and lakes corresponds in time with the engineering modification of the main navigable branch, Sulina. Though Vidrașcu's map shows settlements and roads, so ways of using the territory by local inhabitants, the simplification of navigation that obtains in the same historical period makes it so the interior of the Delta becomes ever more accessible, and therefore ever more exploitable. This in turn gives further incentives for ignoring what Vidrașcu's map clearly shows, namely that the territory was already extensively used by local inhabitants. It is of course not for their benefit that channels are dug and dikes created (they, after all, could navigate the natural Delta just fine).
Despite the substantive interventions above, the most dramatic transformation of the Danube Delta environments occurred after WWII, when its economic function completely changed the entire ecosystem. New artificial channels were built in order to exploit the fish resources existing in deltaic lakes, to harvest reeds, or connect the fluvial arms: RoșulețÎmpuțita, Magearu, Eracle-Batacu, Ciotic, Buhaz, Gotca, Iacob-Batacu, Crișan-Caraorman and Mila 35. The construction of such a dense network of canals almost tripled the water discharge toward the interior of the delta plain (Giosan et al., 2013). Between 1985 and 1990, the meanders of the Sf. Gheorghe arm were shortened, with a decrease in length from $108.2 \mathrm{~km}$ to $69.7 \mathrm{~km}$ (Fig. 3B). The consequences were considerable: an increase in the water flow speed on the artificial courses and a decrease on the natural arms with the formation of new islets.

Harvesting reed in the 1960s generated another impulse for new artificial channels. Fish farms were established over the next decade (1970-1980), some of them in the former reed enclosures (Bălteni, Maliuc, Rusca, Obretin), but many others as new projects (Chilia Veche, Stipoc, Popina, Holbina I and II, Periteașca, Perișor, Ceamurlia). It was an unsuccessful idea because, very soon, the fish farms deteriorated and had secondary effects on soil composition, salinization being the most common one. The aquaculture operations were not a big success either, due to oversized ponds, inefficient management and poor infrastructure (Van Assche et al., 2012). Agricultural polders created in the 1980s are another substantial phase of the anthropogenic impact in the Delta: Pardina, Sireasa, MurighiolDunavăț, Babina, Cernovca (Fig. 5). Draining and new irrigation channels transformed the deltaic space with dramatic consequences for the next years. A comparison of the maps from the beginning of the $20^{\text {th }}$ century with the current distribution of water reveals a reduction in the aquatic surface by $93.2 \mathrm{~km}^{2}$, mainly as a result of draining the lakes for agricultural polders. This environmental change of transforming the natural lakes and marshes into agricultural fields had complex consequences for the entire ecosystem (Fig. 5). 

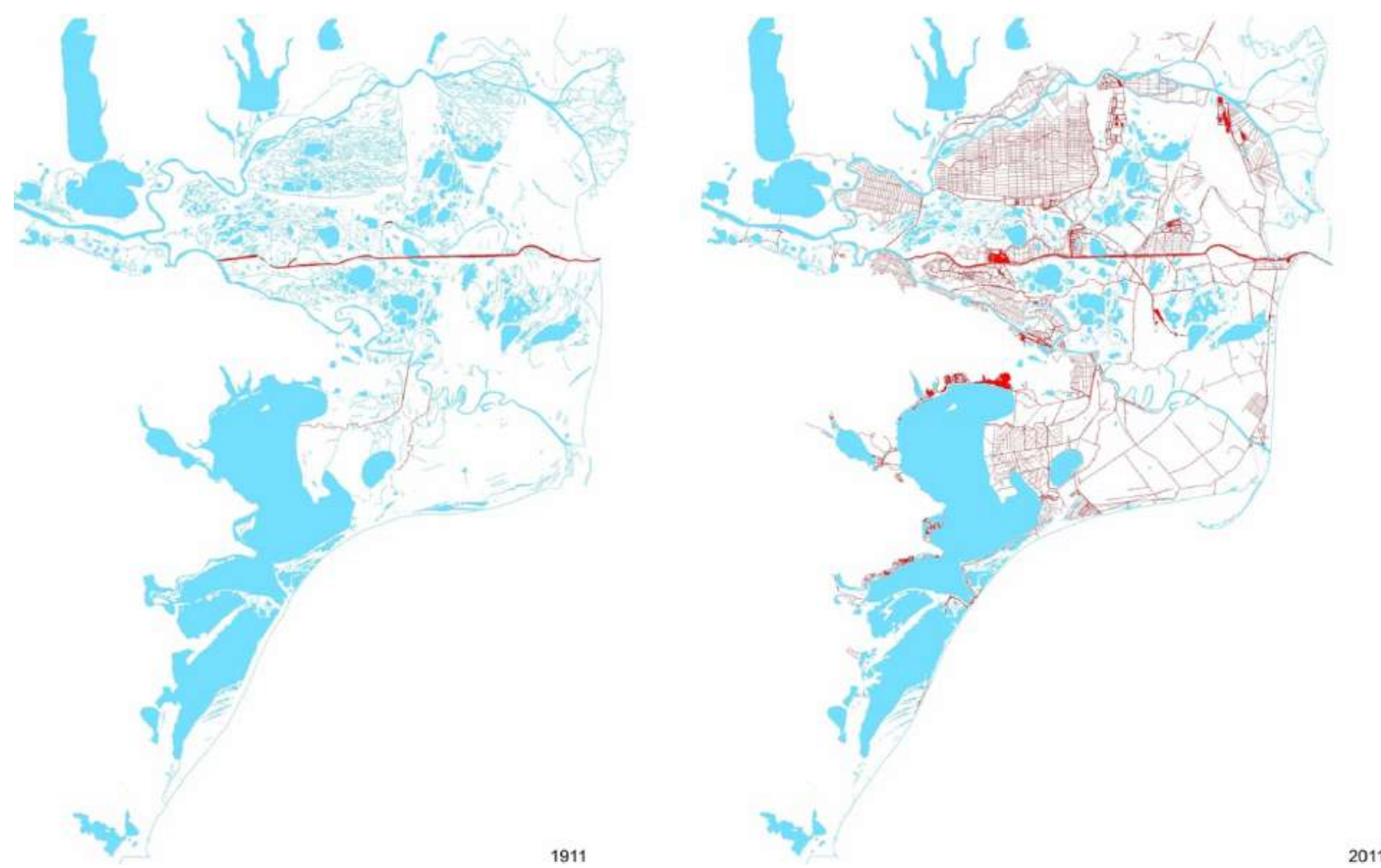

Figure 4 Anthropic channels cut in Danube Delta are represented with red colour in 1911 (left) and in 2011 (right)

The complex of channels, together with the shortening of the main branches, can be seen as a simplification of an otherwise labyrinthine space. Besides aiding in the exploitation of natural resources, these measures also reinforce the centreperiphery dynamic that dictates deltaic exploration. The simplification of the natural form of the Delta is done for the benefit of the representatives of the centre (of power), for whom the complex natural Delta is illegible. For the historic settlements in the Delta, however, the network of natural channels and lakes is just part of a home range that one learns to navigate from birth. As Steinberg and Peters (2015) theorize, "territory - a political technology that combines control of land and terrain with ideas about its capacity for organisation through calculative rationality - is achieved through the control of volumes". The deltaic environment in its natural form is best understood as a world of volume, water being the dominant element that dictates the rhythm of the land as much as that of all beings living within the delta. Its literal transformation into a territory of straight lines leading to predictable and fixed spaces is a profound exercise of power aimed at controlling it in all of its aspects.

The planted forest is another human-induced landscape in the Danube Delta, with forestry being practised in the Rusca, Carasuhat, Pardina, Murighiol, and Sf. Gheorghe enclosures. Some species, like the Canadian poplar, have been used as an alien competitive solution to the willow and resulted in a change of the native fauna composition and of the entire ecosystem (Gâștescu and Știucă, 2008). At present, the entire deltaic space is completely changed after the anthropogenic intervention (Fig. $5)$, and the most dramatic phase belongs to the Communist decades (1950-1989).

\subsection{Aerial perspective}

Topographic maps were the most frequent kind of approach in the $20^{\text {th }}$ century, supplemented after 1960 s by the aerial images used primarily to update the previous products. A first satellite image of the Danube Delta appears in the 1970s, but only few scientists had access to the Landsat archives, dominated in Romania by secrecy and military control. This status will be changed in the 1990s when Land- 
sat and Spot images become a common tool for studying the deltaic landscape. In the present, the new Sentinel products (freely available for download from the European Spacing Agency) constitute the main resource available for a large public.

After 1991, the Danube Delta became a Biosphere Reserve, with new areas defined by this status: strictly protected areas - 9\%; buffer zones 20.7\%; ecological reconstruction areas $-2.7 \%$ which have a tendency to increase over time. The agricultural polders and the fish farms still exist (7\% each), but their efficiency is questioned and their degradation became the main issue. Furthermore, the statistical data associated with their distribution is very often unreliable, and it should be regarded only as an approximation.

The technological advances leading to the aerial perspective - satellite images available with increasing frequency and accuracy - makes possible a view of the territory as ecologically unified, which plays into the current ecological protection model for the area. Relying heavily on the contemporary prestige of the photographic image, the aerial view of the Delta purports to show the territory as it really is, therefore hiding more successfully than ever the collusion between cartographic knowledge and the exercise of power. The contemporary phase of deltaic cartographic knowledge further obscures the multiple dimensions of local knowledge for whom the Delta is a place to be inhabited and not a picture to be divided into zones (see Figure 5).

The phase of ecological protectionism in the history of the Delta should not be understood as a hiatus of anthropogenic impact, but rather itself as the next phase of impact. The Danube Delta Biosphere Reserve regulates the use of the territory strictly and therefore decides which changes are acceptable and which are not. Even when an area is strictly protected, its characteristics change precisely because of the ways in which it is cut off from the greater deltaic space. Fencing forests off (as in the case of Letea), regulating where semi-feral cattle can go, where and what can be fished or hunted, all in the context of a changing climate, is best understood as the next phase of human-induced changes. The civilizing assumption that the Delta is fundamentally empty makes the progression from phase
(1) to (4) inevitably into a progression from empty wilderness to resource exploitation. Even though locals were supposed to exist, their presence was always understood as benign, that is to say as one with no fundamental agency or power over their fate or that of the natural environment. This is contradicted by practices such as reed burning or tree planting that significantly alter the local environment in non-harmful ways. The current protectionist phase fits perfectly well within an anthropogenic history that privileges the rights of the outsider, of the one with the power to describe.

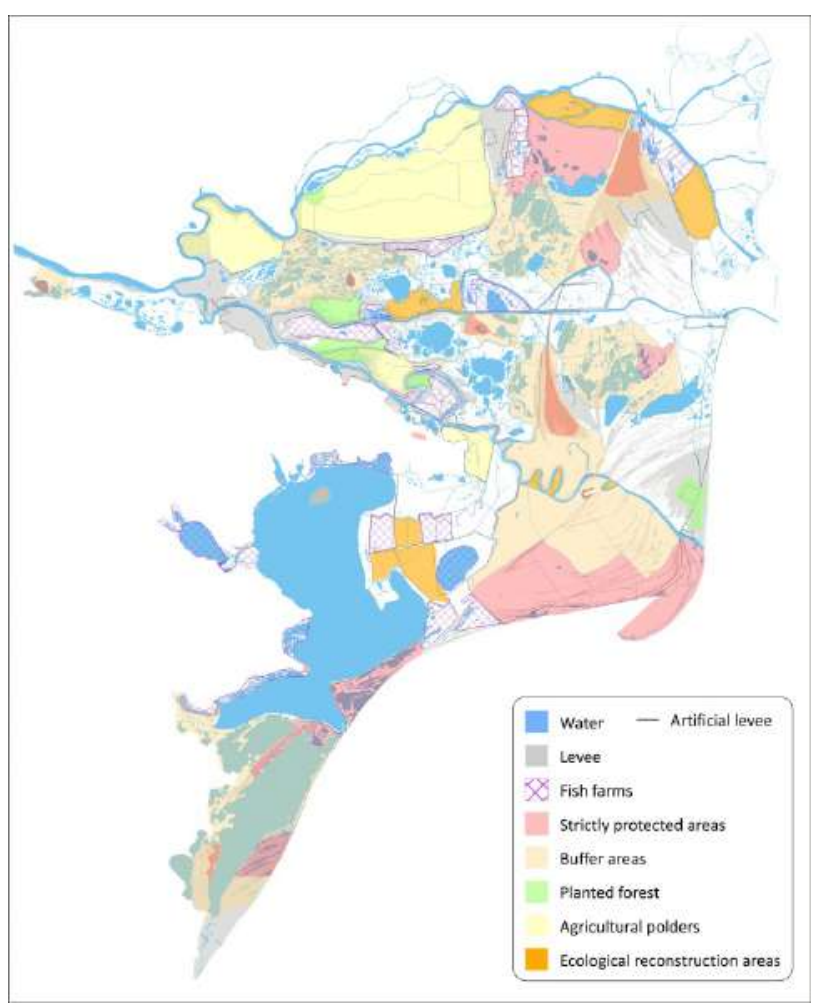

Figure 5 Different types of human-induced environments in the Danube delta (data from Gâștescu and Știucă, 2008)

The engineering of the Delta has further reinforced its accessibility, the volumetric character of the natural environment having been considerably flattened. The current phase of ecological protectionism has not significantly restored the Delta to pre-engineering states and, if current trends are any indication, it will not do so in the foreseeable future.

As with the previous periods of cartographic knowledge aiding certain uses of the territory, so the ecological protectionism prevalent today fa- 
vours certain activities over others. The power to determine which areas are strictly protected and which are available for local economic activities rests with the central authorities, with no local consultations being carried out. This is in keeping with the history of deltaic exploration we have described. The territory as a nature reserve is of great use to tourist operators and big external investors. This is itself in keeping with the current economic expansion of financial capital into areas previously off-limits to its power. The dominant forces in the area are the authorities that impose the rules and regulations of the nature reserve and the economic investors that run business in the area, increasingly focused on leisure activities. The Delta as nature reserve is a story that sells, and the current powers are as invested as naval powers once were in keeping - and showing, through maps - the Delta as a natural wonder.

\section{Conclusions}

In the last decades, efforts have been made to grasp the evolution of the Danube Delta landscape (Antipa, 1914, 1942; Brătescu, 1922; Banu and Rudescu et al., 1965; Panin, 1989, Giosan et al., 2006, Vespremeanu-Stroe et al., 2017). Every delta has its particular issues, and it is difficult to propose a general solution due to the differences in the climate regimes, the liquid and solid discharges, the political administrations or the anthropogenic pressures of each case. Even though each delta is unique, the approach advanced in this study can prove useful for understanding historical changes elsewhere.

We showed that the first stage of cartographic knowledge involved a descriptive and pictorial style with confusing information and many errors related to locations, but those maps were not supposed to aid access to the heart of the Delta but rather to represent it as part of the known world and to inscribe it in the religiously dominated symbolic world order of the day. The mathematical cartography development corresponded to an increase in anthropogenic interventions, the map both aiding and being aided by new means of exploration. The military approach involved bathymetric measurements for fluvial navigation and accurate charting of the coast. The search for economic benefits in the Dan- ube Delta began in the second half of the $19^{\text {th }}$ century, but for other deltas, this could be the case of earlier or later explorations. The natural resources exploitation, which is still ongoing today, produced some dramatic transformations in the deltaic environment: initiation of artificial channels, reed harvesting, fish farms, agricultural polders or even industrial hot spots that completely changed the environment. The political and ideological changes of the early 1990s led to a new status, in this case the Biosphere Reserve one, with its new functional zones overlapping with the traditional ones.

Fishing and animal husbandry were the first human activities that started to transform the Delta, later followed by transit navigation and commercial activities. Economic exploitation led to the most significant changes in the deltaic environment through agriculture, the creation of fish farms, forestry enclosures, and even industrial activities. Even though the habitats' conservation umbrella is protecting some small parts of the Delta, new ecological restoration areas will still have to change the functionality of unsuccessful agricultural, aquaculture or forestry experiments, in the difficult context of climate change. And in spite of all these human interventions in the natural environment, the Danube Delta still remains a global biodiversity hotspot and a better-preserved wetland, compared to other similar deltas (Giosan et al., 2014). Learning about the inaccessible deltaic spaces is a complicated process, which requires a long period, spent first along the coast, then along the main branches and finally inland. Therefore, a cartographical diagnosis could be the most suitable tool for understanding the complex changes occurring in river deltas and how these are inseparable from wider political and ideological considerations. This approach could be complemented with local accounts of the territory in order to reveal the cultural meanings of land-use practices, without which any sustainable use of the deltaic territory is doomed. The phases of deltaic exploration have all supposed an empty land, and this has both made possible the exploitation of the territory by outsiders and has buried land-use practices that could be used in future adaptive strategies. The coastal lowlands that are located less than a meter above sea level will be inundated by the 
turn of the century (Giosan et al., 2014), therefore raising new challenges. In order to be prepared for such scenarios, we need to turn to the past to explain our surroundings. An appropriate solution would be to re-assess our historical maps and to examine them for a better understanding of our future. We can also re-evaluate the assumptions at the basis of our cartographic relation with the Delta. There, we stand a chance to discover historic local practices that can show the way to a more benign anthropic impact and a fairer distribution of power. The protectionist phase, in incorporating human agency, might then be able to propose a dynamic and adaptable human ecology, and not a return to a past that never existed.

\section{References}

Akerman JR. 2009. The imperial map: cartography and the mastery of empire. Chicago, University of Chicago Press.

Antipa, G., 1895. Studii asupra pescăriilor din Romănia. Imprimeria Statului (p.80)

Antipa G. 1914. Dunărea și problemele ei științifice, economice și politice. București, Librăriile Cartea Românească și Pavel Surdu.

Antipa G. 1942. Valorificarea stufăriilor Deltei Dunării. Ann. Acad. Rom (Vol. XVIII), București.

Banu AC, Rudescu L. 1965. Delta Dunării. București, Editura Științifică.

Blackbourn D. 2011. The conquest of nature: water, landscape, and the making of modern Germany. Random House.

Brătescu C. 1922. Delta Dunărei. Geneza și evoluția sa morfologică și cronologică. Buletinul Societății Române de Geografie, XXXXXI.

Budileanu M. 2013. Evolution of the Sulina mouth bar (Danube River). Revista de Geomorfologie, 15: 49-55.

Cioc M. 2002. The Rhine. An eco-biography, 1815-2000, pp.173-201.

Constantinescu Ș. 2014. Various approaches to the Danube Delta: from maps to reality. In: The bio-politics of the Danube Delta. Nature, history, policies (p. 482). Lexington Books.

Constantinescu Ș, Giosan L, Vespremeanu-Stroe A. 2010. A cartographical perspective to the engineering works at the Sulina mouth, the Danube Delta. Acta Geodaetica et Geophysica Hungarica, 45(1): 71-79. http://doi.org/10.1556/AGeod.45.2010.1.11

Constantinescu Ș, Achim D, Rus I, Giosan L. 2015. Embanking the Lower Danube: from natural to engi- neered floodplains and back. In: Hudson PF and Middelkoop H. (eds.): Geomorphic approaches to integrated floodplain management of lowland fluvial systems in North America and Europe (pp. 265-288). New York, NY: Springer New York. Retrieved from http://link.springer.com/10.1007/978-1-4939-23809_11.

Dorondel S. 2005. The "Voices" of the Romanian integration into EU: land and environmental practices in a village from Dobrudja. Anthropology of East Europe Review, 23(2): 30-40

Dorondel S, Mitroi V. 2017. Nature, state and conservation in the Danube Delta: turning fishermen into outlaws. In: von Hardenberg WG, Kelly M, Leal C, Wakild E. (eds.): The nature state: rethinking the history of conservation. Routledge.

Edney M. 2009. The irony of imperial mapping. In: The imperial map: cartography and the mastery of empire. Chicago: University of Chicago Press.

Retrieved from http://www.press.uchicago.edu/ucp /books/book/chicago/I/bo5813558.html

Elden S. 2013. Secure the volume: Vertical geopolitics and the depth of power. Political Geography 34: 35-51.

Enăchescu V-A. 2013. Understanding multicultural Dobrogea. Journal of Community Positive Practice, XIII(2): 108-115.

Gătejel L. 2016. Overcoming the Iron Gates: Austrian transport and river regulation on the Lower Danube, 1830s-1840s. Central European History, 49(2): 162180.

Gătejel L. 2017. Imperial cooperation at the margins of Europe: the European Commission of the Danube, 1856-65. European Review of History (Revue européenne d'histoire), 24(5): 781-800.

Gătejel L. 2018. Building a better passage to the sea. Engineering and river management at the mouth of the Danube, 1829-61. Technology and Culture (Erscheint voraussichtlich), 58(3): 1-36

Gâștescu P, Știucă R. 2008. Delta Dunării, rezervație a biosferei. București, CD Press.

Giosan L, Donnelly JP, Constantinescu Ș, Filip F, Ovejanu I, Vespremeanu-Stroe A, Vespremeanu E, Duller GAT. 2006. Young Danube delta documents stable Black Sea level since the middle Holocene: Morphodynamic, paleogeographic, and archaeological implications. Geology, 34(9): 757-760. http://doi.org/10.1130/G22587.1

Giosan L, Coolen MJL, Kaplan JO, Constantinescu Ș, Filip F, Filipova-Marinova M, Kettner AJ, Thom N. 2012. Early anthropogenic transformation of the Danube-Black Sea system. Scientific Reports, 2: 1-6 http://doi.org/10.1038/srep00582. 
Giosan L, Constantinescu Ș, Filip F, Deng B. 2013. Maintenance of large deltas through channelization: nature vs. humans in the Danube delta. Anthropocene, 1: 35-45. http://doi.org/10.1016/j.ancene.2013.09.001

Giosan L, Syvitski J, Constantinescu S, Day J. 2014. Climate change: protect the world's deltas. Nature, 516(7529): 31-33. http://doi.org/10.1038/516031a

Ionescu-Siseşti G. 1933. Lunca Dunării şi punerea ei în valoare. Bucureşti.

Iordachi C, Assche KV. (eds.) 2015. The biopolitics of the Danube Delta: nature, history, policies. Lexington Books, Lanham, Maryland.

Kideys AE. 2002. ECOLOGY: Enhanced: fall and rise of the Black Sea ecosystem. Science, 297(5586): 1482-1484. http://doi.org/10.1126/science.1073002

Levis C, Costa FR, Bongers F, Peña-Claros M, Clement CR, Junqueira $A B, \ldots$ Castilho CV. 2017. Persistent effects of pre-Columbian plant domestication on Amazonian forest composition. Science, 355(6328): 925-931.

McCarney-Castle K, Voulgaris G, Kettner AJ, Giosan L. 2012. Simulating fluvial fluxes in the Danube watershed: The "Little Ice Age" versus modern day. The Holocene, 22(1): 91-105.

http://doi.org/10.1177/0959683611409778

Panin N. 1989. Danube delta. Genesis, evolution and sedimentology. Revue Roumaine de Geologie, Geophisique, Geographie, 33: 25-36.

Prelz Oltramonti G, Tănăsescu M. 2018. The criminalization of informal practices in the Danube Delta: how and why. In: Polese A, Russo A. (eds.): The illegal, the immoral and the criminal: transnational perspectives on informality. London: Routledge.

Pritchard SB. 2011. Confluence: the nature of technology and the remaking of the Rhône. Harvard historical studies. Harvard University Press, Cambridge Mass. (p. 371)

Rosetti C, Rey F. 1931. La Commission Européenne du Danube et son oeuvre de 1856 a 1931. Paris: Imprimerie Nationale.

Rudescu L, Niculescu C, Chivu IP. 1965. Monografia stufului din Delta Dunării. București: Editura Academiei Republicii Socialiste Romania.

Stanciu N, Neicu S, Buruian S. 2008. Aspecte privind riscul hidric generat de extremele pluviometrice în zona Luncii Dunării. Dunărea, Lunca şi Delta Dunării. Agricultură şi Mediu. Prezent şi Perspectivă, 37-64.

Steinberg PE. 2009. Sovereignty, territory, and the mapping of mobility: A view from the outside. Annals of the Association of American Geographers, 99(3): 467495.

Steinberg P, Peters K. 2015. Wet ontologies, fluid spaces: Giving depth to volume through oceanic thinking.
Environment and Planning D: Society and Space, 33(2): 247-264.

Syvitski JPM. 2005. Impact of humans on the flux of terrestrial sediment to the Global Coastal Ocean. Science, 308(5720): 376-380.

http://doi.org/10.1126/science.1109454

Syvitski JPM, Saito Y. 2007. Morphodynamics of deltas under the influence of humans. Global and Planetary Change, 57(3-4): 261-282.

http://doi.org/10.1016/j.gloplacha.2006.12.001

Syvitski JPM, Kettner AJ, Overeem I, Hutton EWH, Hannon MT, Brakenridge GR, Day J, Vorosmarty C, Saito Y, Giosan L, Nicholls RJ. 2009. Sinking deltas due to human activities. Nature Geoscience, 2(10): 681-686. http://doi.org/10.1038/ngeo629

Tănăsescu M. 2017. Field notes on the meaning of rewilding. Ethics, Policy \& Environment, 20(3): 333-349.

Ter Steege H, Pitman NC, Sabatier D, Baraloto C, Salomão RP, Guevara JE, ... Monteagudo A. 2013. Hyperdominance in the Amazonian tree flora. Science, 342(6156): 1243092-1243092.

Van Assche K, Devlieger P, Teampau P, Verschraegen G. 2009. Forgetting and remembering in the margins: constructing past and future in the Romanian Danube Delta. Memory studies, 2(2): 211-234.

Van Assche K, Beunen R, Jacobs J, Teampau P. 2011 a. Crossing trails in the marshes: rigidity and flexibility in the governance of the Danube Delta. Journal of Environmental Planning and Management, 54(8): 9971018.

Van Assche K, Duineveld M, Beunen R, Teampau P. 2011b. Delineating locals: transformations of knowledge / power and the governance of the Danube Delta. Journal of Environmental Policy \& Planning, 13(1): 121.

Van Assche K, Bell S, Teampau P. 2012. Traumatic natures of the swamp: concepts of nature in the Romanian Danube Delta. Environmental Values, 21(2): 163-183. http://doi.org/10.3197/096327112X13303670567297

Vespremeanu-Stroe A, Preoteasa L, Zăinescu F, Tătui F. 2017. The evolution of Danube Delta after Black Sea reconnection to World Ocean. In: Rădoane $\mathrm{M}$, Vespremeanu-Stroe A. (eds.): Landform Dynamics and Evolution in Romania. Springer International Publishing, Cham, pp. 521-549. https://doi.org/10.1007/9783-319-32589-7_22

von Hardenberg WG, Kelly M, Leal C, Wakild E. (eds.) 2017. The Nature State: Rethinking the History of Conservation. Routledge (p. 228)

Vörösmarty CJ, Syvitski J, Day J, de Sherbinin A, Giosan L, Paola C. 2009. Battling to save the world's river deltas. Bulletin of the Atomic Scientists, 65(2): 31-43. http://doi.org/10.2968/065002005 